\title{
ANALISIS KEBUTUHAN INSTRUKSIONAL DI SDN KEBON BESAR 1
}

\author{
Nur Herni Hernawati Dewi ${ }^{1}$, Nur Suci Ramadhanty ${ }^{2}$, Nur Wilda Akmalia ${ }^{3}$ \\ Universitas Muhammadiyah Tangerang \\ nurherni644@gmail.com,nursuciramadhanty22@gmail.com
}

\begin{abstract}
This research intends to understand some of the needs that exist in SDN Kebon Besar 1. And to know some of the weaknesses and advantages of learning needs at the SDN. This observation uses a qualitative descriptive method. The results of the analysis of this study note that the most important learning needs are books, teacher handbooks and student books. If one is inadequate, then the learning process will not run, because the book is a reference in the implementation of the learning process. Next, the most important requirement is the media in learning. Because if the media does not exist, it will hamper a learning process. What inbibits the absence of media, namely when the budget is late given and poor budget management.
\end{abstract}

Keywords: Learning Needs, Learning Process, Media

\begin{abstract}
Abstrak: Penelitian ini bermaksud demi memahami beberapa kebutuhan yang ada di SDN Kebon Besar 1. Serta mengetahui beberapa kelemahan dan keunggulan kebutuhan pembelajaran di SDN tersebut. Observasi ini memakai metode deskriptif kualitatif. Hasil analisis dari penelitian ini diketahui bahwa kebutuhan pembelajaran yang paling utama yaitu buku, buku pegangan guru dan buku siswa. Jika salah satu tidak memadai, lalu proses pembelajaran tidak akan berjalan, karena buku itu sebagai acuan dalam terlaksananya proses pembelajaran. Selanjutnya, kebutuhan yang paling penting yaitu media dalam pembelajaran. Karena jika media tersebut tidak ada, maka akan menghambat sebuah proses pembelajaran. Yang menghambat tidak adanya media, yaitu ketika anggaran terlambat
\end{abstract}

Kata Kunci: Kebutuhan Pembelajaran, Proses Pembelajaran, Media

\section{PENDAHULUAN}

Pendidikan adalah kebutuhan utama manusia. Pendidikan merupakan hal yang dinamis. Kemajuan dan pembaruan sesuai dengan perkembangan di segala bidang kehidupan. kemajuan dan pembaruan dalam bidang pendidikan mencakup berbagai faktor yang terlibat di dalamnya baik itu implementasi pendidikan di lapangan yaitu kompetensi guru dan kualitas tenaga pendidik, mutu pendidikan, perangkat kurikulum, sarana dan prasarana pendidikan dan mutu menejemen pendidikan termasuk perubahan dalam metode dan strategi pembelajaran yang lebih

Fondatia : Jurnal Pendidikan Dasar

Volume 4, Nomor 1, Maret 2020; 48-52

https://ejournal.stitpn.ac.id/index.php/fondatia 
inovatif. Usaha dalam kemajuan dan pembaruan tersebut bermaksud untuk membawa karakter pendidikan Indonesia lebih baik.

Memasuki masa era globalisasi, bangsa Indonesia tidak ada habis nya selalu melakukan perluasan disegala bidang kehidupan baik perluasan material maupun spiritual termasuk di dalamnya sumber daya manusia, salah satu faktor yang menunjang perluasan atau pengembangan sumber daya manusia yaitu melalui pendidikan mendapat tempat utama.

Kebutuhan dalam metode belajar sangat penting, karena kebutuhan dalam belajar merupakan akar yang mengilustrasikan jarak antara tujuan belajar yang diinginkan oleh peserta didik atau keadaan belajar yang sebenarnya. Setiap peserta didik memiliki kebutuhan yang berbeda-beda hal ini perlu pengenalan untuk menentukan kebutuhan mana yang dimiliki peserta didik yang terpendam dan alhasil menjadi kebutuhannya.

Dalam cara untuk mencapai proses pembelajaran yang dibutuhkan oleh peserta didik, maka peran pendidik (guru) dalam mengajar akan menjadikan suatu aspek utama keberhasilan tercapai atau tidaknya suatu tujuan pembelajaran. Seorang pendidik perlu melakukan pengenalan terlebih dahulu kepada masing-masing peserta didiknya, hal ini berguna untuk apa yang telah disampaikan oleh pendidik dalam proses pembelajaran dapat diterima dengan baik oleh peserta didik.

\section{METODE PENELITIAN}

Observasi ini memakai pendekatan kualitatif yang dimana penelitian ini cenderung meggunakan analisis. Untuk menganalisis tersebut digunakan metode wawancara sebagai bentuk observasi yang dilakukan. Dimana wawancara ini menggunakan beberapa pertanyaan sebagai bahan untuk dianalisis pada pembahasan ini. Hasil dalam metode wawancara ini diketahui bahwa kebutuhan pembelajaran yang paling utama yaitu buku, buku pegangan guru dan buku siswa. Jika salah satu tidak memadai, lalu proses pembelajaran tidak akan berjalan, karena buku itu sebagai acuan dalam terlaksananya proses pembelajaran. Selanjutnya kebutuhan yang paling penting yaitu media dalam pembelajaran. Karena jika media tersebut tidak ada, maka 
akan menghambat sebuah proses pembelajaran. Yang menghambat tidak adanya media, yaitu ketika anggaran terlambat diberikan dan pengelolaan anggaran yang kurang baik. Lebih jelasnya terdapat di pembahasan.

\section{HASIL DAN PEMBAHASAN}

Hasil dari penelitian ini yaitu dimana media adalah sesuatu yang paling dibutuhkan sekolah sebagai suatu kebutuhan dalam pembelajaran, seperti media elektronik yaitu infocus dan juga gambar-gambar. Media yang digunakan dalam pembelajaran di setiap tingkatan kelas berbeda karena masing-masing tingkatan kelas kebutuhan nya berbeda begitupun dengan aspek-aspek nya seperti aspek kognitif, afektif dan psikomotorik. Contoh pada kelas tinggi yaitu dalam pembelajaran IPA ada materi seperti organ-organ tubuh, pernapasan dan juga ekosistem, pada materi itu di gunakan benda-benda konkret seperti patung yang terdapat organ tubuhnya. Dan pada kelas rendah menggunakan benda-benda konkret yang dapat mereka aplikasikan juga atau memainkan games untuk lebih memudahkan dalam pembelajaran, karena pada usia kelas rendah anak-anak lebih cepat memahami dan lebih mengingat dengan hal-hal yang mereka senangi. Media di sekolah itu sendiri sudah terpenuhi karena sekolah memfasilitasi media tersebut, seperti laptop, infocus, gambar-gambar dan juga internet. Untuk menjalankan media elektronik, tidak semua pendidik bisa menjalankan nya, maka dari itu tidak semua kelas menggunakan media tersebut. Inilah suatu kebutuhan yang masih kurang di sekolah ini, yaitu beberapa pendidik yang kurang pandai dalam menggunakan media elektronik. Jika media-media tersebut tidak memadai, maka proses pembelajaran akan terhambat, karena media tersebut sangat penting atau menjadi faktor utama dalam tercapai nya proses pembelajaran. Di tambah dengan zaman yang saat ini sedang berkembang dalam teknologi nya, media elektronik adalah aspek terpenting dalam membantu mempermudah pendidik dalam berlangsung nya proses pembelajaran, karena media elektronik tidak membosankan sehingga sangat disenangi para peserta didik. Oleh karena itu pendidik di zaman sekarang harus dapat menggunakan media elektronik seperti laptop dan infocus. 
Selain media elektronik, kebutuhan lain yang paling utama yaitu buku. Buku terbagi menjadi 2 macam, buku pegangan guru dan buku pegangan siswa. Jika buku tersebut tidak memadai, maka pembelajaran tidak akan berlangsung, karena buku adalah sumber utama dalam proses pembelajaran. Maka dari itu, buku menjadi sumber paling utama untuk terlaksana atau tidaknya suatu pembelajaran.

Terpenuhi atau tidaknya suatu kebutuhan yaitu tergantung anggaran dari pemerintah serta pengelolaan yang sesuai, karena untuk memenuhi kebetuhan tersebut sekolah membeli fasilitas media untuk pembelajaran seperti buku, laptop, infocus, serta media-media lain melalui anggaran yang di alokasikan dari pemerintah. Jika anggaran tersebut terlambat sampai pada sekolah, maka proses belajar mengajar pun akan terhambat bahkan tidak berjalan. Karena jika tidak ada media seperti buku dan media elektronik, para pendidik akan sulit bahkan tidak bisa untuk memulai suatu pembelajaran. Begitupun dengan pengelolaan yang sesuai, maka semua kebutuhan pembelajaran akan terpenuhi dan pembelajaran akan terlaksana dengan baik.

Kemudian kebutuhan selanjutya dalam ekstrakulikuler pramuka. Fasilitas yang kurang memadai seperti di dalam kegiatan persami yaitu tenda dan toya. Sedangkan dalam ekstrakulikuler bulutangkis, kebutuhan atau fasilitas yang kurang memadai yaitu lapangan bulutangkis. Karena satu lapangan digunakan untuk semua kegiatan. Maka dari itu kegiatan ekstrakulikuler ini harus di perhatikan dalam kebutuhan nya agar peserta didik dapat terbentuk aspek afektif maupun aspek psikomotorik nya

\section{KESIMPULAN}

Kesimpulan dari penelitian ini adalah bahwa kebutuhan pembelajaran yang paling utama ialah media, seperti buku. Buku pegangan guru serta buku pegangan siswa. Jika buku tidak ada, maka proses pembelajaran tidak akan berjalan. Karena buku menjadi faktor utama dalam terlaksana nya pembelajaran. Kebutuhan yang paling utama selanjutnya ialah media. Dimana media menjadi faktor utama kedua setelah buku. Media adalah faktor utama untuk tercapainya proses pembelajaran. 
Nur Herni Hernawati Dewi, Nur Suci Ramadhanty, Nur Wilda Akmalia

Karena jika tidak ada media, maka proses belajar mengajar akan terhambat dan proses belajar mengajar pun tidak akan berjalan dengan baik.

\section{DAFTAR PUSTAKA}

Magdalena, Ina. 2018, Desain Pembelajaran SD, FKIP UMT Press: Tangerang. https://khanfarkhan.com/faktor-yang-mempengaruhi-kebutuhan-manusia/ Asep Saripudin, wawancara, Tangerang 02 Desember 2019 